\title{
Respiratory syncytial virus infection in children under one year of age hospitalized for acute respiratory diseases in Pelotas, RS
}

\author{
Silvia Elaine Cardozo Macedo ${ }^{1}$, Ana Maria Baptista Menezes ${ }^{2}$, Paulo Post ${ }^{3}$, Elaine AlbernaZ ${ }^{4}$, Marli Knorst ${ }^{5}$
}

Introduction: Acute respiratory diseases (ARDs) are a major cause of infant morbidity and mortality. Objective: The present case-controlled study investigated the hospitalizations by $A R D$ s in children under one year of age and the association with the respiratory syncytial virus (RSV) in za Pelotas, RS. Methods: All children under one year of age hospitalized due to ARDs

from August 1997 to July of 1998 were followed-up in the four hospitals of the city. A standardized questionnaire was applied to the children's mother regarding symptoms of the actual illness in addition to social and demographic variables, nutrition, and previous morbidity.

The final diagnosis of ARDs was performed by an arbiter (a pediatrician) based on the hospital records of the children and the data on the questionnaire. Nasopharyngeal secretions were collected for RSV detection by direct immunofluorescence. Results: The study included 650 children and the annual incidence rate of hospital admissions for ARDs was 13.9\%. Admissions showed a seasonal pattern with most of the hospitalizations occurring from July to October. The main causes of admission were: pneumonia (43.7\%), bronchiolitis (31.0\%), asthma (20.3\%), influenza (3.5\%), otitis media (0.8\%) and laryngitis (0.6\%). The overall prevalence of RSV was

$30.7 \%$, with $40.2 \%$ in bronchiolitis, $28.6 \%$ in influenza, $27.4 \%$ in asthma, $26.3 \%$ in pneumonia, and $25 \%$ in otitis media. Conclusions: The results of the present study confirm the high morbidity of ARDs in childhood and the seasonal pattern of ARDs hospitalizations and their association with RSV infection. (J Pneumol 2003;29(1):4-8)

Key words - Acute respiratory diseases. Children. Incidence. Pneumonia. Respiratory syncytial virus.

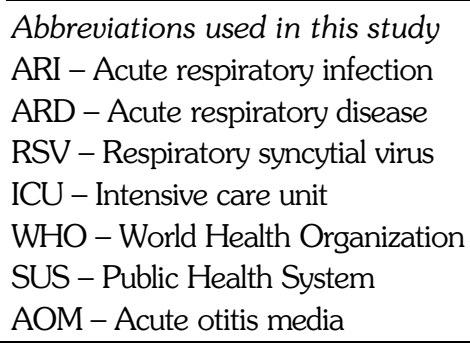

* This study was performed in the Universidade Federal do Rio Grande do Sul (UFRS), RS. Dissertation presented at the Graduate Program of Pneumology of UFRS in October 20, 2000 to obtain a Master's Degree.

1. Assistant Professor of Pneumology of Universidade Federal de Pelotas. Master in Pneumology from UFRS.

2. Full Professor of Pneumology of Universidade Federal de Pelotas. Ph.D. in Pneumology from UFRS.

3. Associate Professor of Microbiology of Universidade Federal de Pelotas. Ph.D. in Microbiology from UFRJ.

4. Assistant Professor of Pediatrics of Universidade Católica de Pelotas. Ph.D. in Epidemiology from Universidade Federal de Pelotas.

5. Associate Professor of the Department of Internal Medicine of UFRS. Ph.D. in Pneumology from Johannes Gutenberg University Mainz, Germany.

Mailing address - Rua Domingos Guedes Cabral, 440/203 - 96030-310 - Pelotas, RS. E-mail: secmacedo@aol.com

Received for publication in 04/16/02. Approved after revision in 10/28/02. 


\section{INTRODUCTION}

Acute respiratory diseases (ARDs), especially acute respiratory infections (ARIs), are one of the most common causes of morbidity-mortality in infancy, mainly reaching children under five years of age. Despite the reduction of mortality due to ARIs observed both in developed countries as well as developing countries, the magnitude of this reduction was much higher among the former and morbidity remains significant in both ${ }^{(1)}$. Data from OPAS/WHO in Latin America concerning the prevalence and incidence of ARIs demonstrate that this is the main cause of pediatric ambulatory appointments, representing 40 to $60 \%$ of the reasons for consultations in this groups ${ }^{(2)}$. Similar data are observed in Rio Grande do Sul (RS) State during winter ${ }^{(3)}$. In Pelotas (RS), a longitudinal follow-up study with children born in 1993 demonstrated that pneumonia was the second most frequent cause of hospitalization in the first year of life $e^{(4)}$. A transversal survey performed in the same city with 6 month-old children detected a prevalence of ARIs referred in the last week of $43.7 \%^{(5)}$.

Among the countless ARIs etiological agents, viruses are acknowledged to be predominant, particularly in developed countries, especially the respiratory syncytial virus (RSV), the most frequent among ARIs of lower airways, such as bronchiolitis and pneumonia, mainly in children under 1 year of age $e^{(6,7)}$.

The purpose of the present study was to analyze hospitalization due to ARD in children under 1 year of age, in the city of Pelotas, assessing the prevalence of RSV infection.

\section{METHODS}

All children admitted (pediatric ICUs and wards) in four hospitals of the town, from zero to one year old, with diagnostic of ARD at hospital release, between August $1^{\text {st }}, 1997$ and July $31^{\text {st }}, 1998$, were included in the study. Subsequently, an independent arbiter (pediatrician) revised all information collected, from the medical chart and a questionnaire of symptoms filled by the mother or responsible and, based on criteria proposed by the WHO, decided on the child's respiratory diagnosis ${ }^{(1)}$. The children whose available clinical data were considered insufficient or who did not have ARD diagnosis according the criteria used by the arbiter were excluded from the study. Daily visits were made to the four hospitals of the town and children with diagnosis of ARD at hospital discharge were identified and submitted to aspiration of nasopharyngeal secretion for search of RSV by direct immunofluorescence. The mothers answered a structured and pre-codified questionnaire concerning social and birth conditions, history of morbidity and specific questions about symptoms and current features.

During the study period, 874 children up to one year old were hospitalized, with a diagnostic of ARD in the chart and hospital release. Refusals and losses reached $8.8 \%$ of the sample (57 cases), resulting in 817 hospitalizations. Eighty one cases were excluded due to the following reasons: insufficient available data to generate adequate diagnostic by the judge or because the judge did not give a diagnostic of ARD. Total sample size was 736 . Five hundred and seventy nine of these children were admitted only once and 157 were readmitted with ARD at least once. In the group of children readmitted with $\mathrm{ARD}$, only the data concerning the first admission were analyzed, corresponding to 71 cases, adding up to 650 hospitalizations.

From the known number of children up to one year old in the city of Pelotas, obtained in the census of 1991 and 1996, the number of children in this age range in 1998 an estimated, reaching a denominator to calculate the incidence of hospitalizations from ARD in the study period.

The project was approved by the Ethics Committee of the School Hospital of "University Support Foundation of Pelotas Medical School". Data and respiratory secretion were collected after written consent of the mothers, assuring absolute confidentiality on information obtained.

\section{RESULTS}

The incidence of hospitalizations due to ARD in children up to one year old, in the city of Pelotas, was $13.9 \%$. Table 1 shows the distribution of this hospitalizations according to the demographic, socioeconomic, nutritional and morbidity characteristics of the children. 
TABLE 1

Demographic, social, nutritional and morbid characteristics of 650 children hospitalized for acute respiratory disease in Pelotas, RS, from July 1997 and August 1998

\begin{tabular}{|c|c|c|}
\hline \multirow[b]{2}{*}{ Variables } & \multicolumn{2}{|c|}{ Cases } \\
\hline & $\mathbf{N}$ & $\%$ \\
\hline \multicolumn{3}{|l|}{ Sex } \\
\hline Male & 373 & 57.4 \\
\hline Female & 277 & 42.6 \\
\hline \multicolumn{3}{|l|}{ Age } \\
\hline 0 to 6 months & 438 & 67.4 \\
\hline 7 to 12 months & 212 & 32.6 \\
\hline \multicolumn{3}{|l|}{ Family income } \\
\hline Up to $1 \mathrm{MW}$ & 245 & 38.5 \\
\hline 1.1 to $3 \mathrm{MW}$ & 239 & 37.5 \\
\hline 3.1 to $6 \mathrm{MW}$ & 114 & 17.9 \\
\hline More than $6 \mathrm{MW}$ & 39 & 6.1 \\
\hline \multicolumn{3}{|l|}{ Birth weight } \\
\hline Less than $2,500 \mathrm{~g}$ & 98 & 15.1 \\
\hline More than 2,500g & 552 & 84.9 \\
\hline \multicolumn{3}{|l|}{ Lactation } \\
\hline Less than 6 months & 420 & 64.6 \\
\hline Still nurses or more than 6 months & 230 & 35.4 \\
\hline \multicolumn{3}{|l|}{ Smoking mother } \\
\hline Yes & 291 & 44.7 \\
\hline No & 359 & 55.3 \\
\hline \multicolumn{3}{|l|}{ Respiratory antecedents } \\
\hline Pneumonia & 59 & 9.1 \\
\hline Screeching with short of breath & 185 & 69.8 \\
\hline
\end{tabular}

$\mathrm{MW}$ - minimum wage

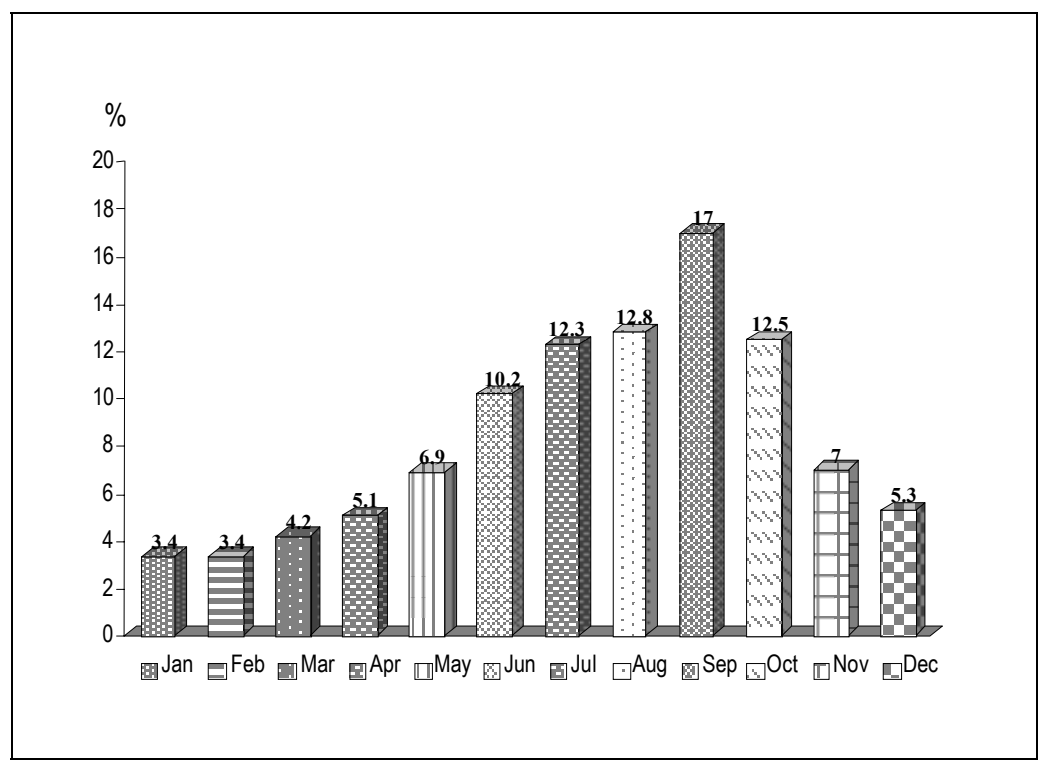

Figure 1 - Monthly distribution of hospitalizations for ARD in children under one year of age, throughout 12 months, in Pelotas, RS $(N=650)$. 
Distribution of admissions due to ARD in children under one year of age throughout 12 months is presented in Figure 1. In the period between July and October, approximately $55 \%$ of admissions took place, being most of them in September (17.0\%).

The most frequent causes of hospitalizations, according to the arbiter of the study were pneumonia (43.7\%), bronchiolitis (31.0\%), asthma (20.3\%), flu (3.5\%), acute otitis media $(0.8 \%)$ and laryngitis $(0.6 \%)$.

Regarding the clinical features, the most frequent symptoms in decreasing order were cough $(95.5 \%)$, tachypnea (92.2\%), sibilance (93.4\%), expectoration (78.4\%), fever $(70.9 \%)$, draught $(66.4 \%)$, nose wing beat $(57.3 \%)$ and cyanosis (37.9\%).

RSV search was performed in 608 children (93.5\% of the cases). Prevalence of positive RSV in the respiratory secretion of these children was $30.7 \%$ and its distribution among specific groups of ARD is illustrated in Figure 2. Approximately $40 \%$ of the children with diagnosis of bronchiolitis were positive for RSV in the respiratory secretion.

Concerning seasonality of RSV infection (Figure 3), the distribution of positive virus in these children's respiratory secretion during 12 months was similar to the admissions due to ARD (Figure 1). RSV infections were concentrated between July and October.

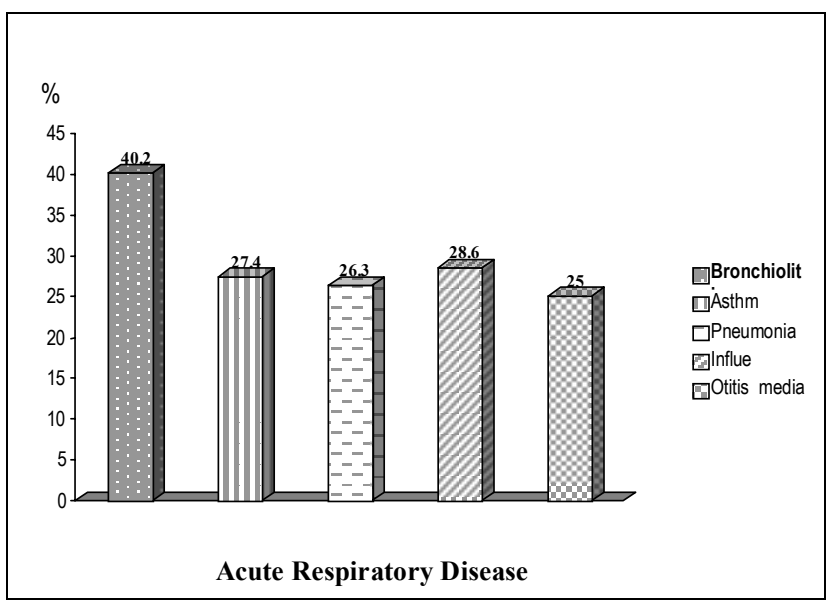

Figure 2 - Positive respiratory syncytial virus for specific groups of acute respiratory disease in children under one year of age, in Pelotas, RS ( $\mathrm{N}=608)$.

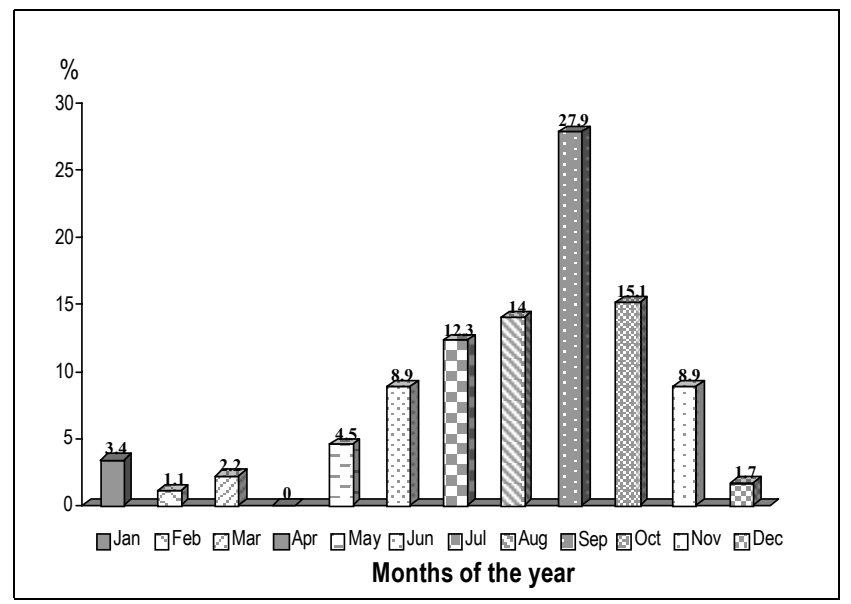

Figure 3 - Monthly distribution of positive respiratory syncytial virus in children under one year of age, in Pelotas, RS ( $N=$ 608).

\section{DISCUSSION}

Acute respiratory diseases are one of the major causes of children morbidity and mortality in the world, especially in the first year of life. Incidence of hospitalizations due to ARD in children under one year of age observed in the present study - $13.9 \%$ - reinforces the importance of this condition in our environment. Seven hundred and thirty six hospitalizations occurred on account of ARD in children under one year of age, within a period of 12 months, and of these 157 children were readmitted once or more for ARD. This group of children deserves a separate analysis in the future, since it probably presents peculiarities that make it a differentiated risk of morbidity. Data from the Health Ministry confirm the importance of ARD as a significant cause of morbiditymortality in the infant population, especially in the first year of life ${ }^{(8,9)}$. In comparison to statistics of other developing countries, the incidence of ARD observed in the present series was higher. A study performed in Gambia reports a $9.6 \%$ annual incidence of hospitalizations for acute respiratory infection in children under two years of age. It is worth emphasizing, however, that in the present study admissions due to bronchial asthma were also included, which may be the reason for the higher incidence detected ${ }^{(10)}$.

As it happens in other Brazilian series ${ }^{(8,9)}$ and in other countries of the world ${ }^{(11-16)}$, pneumonia was the most frequent cause of hospitalizations for ARD, reflecting the severity of this clinical condition as a potential cause of mortality in small children ${ }^{(3)}$. It is important to mention, however, that difficulties to obtain a bed in the public 
health system, as well as the difficulty to treat the disease at home, especially due to the social problem, may underor overestimate, respectively, the real need for hospitalization due to this clinical condition, which is the admission or Berkson's ${ }^{(17)}$ bias.

The concentration of admissions between July and October is related to the lower temperatures. Environmental factors, associated to cold temperatures, especially domestic confinement and contamination by organic residues are responsible for higher respiratory morbidity and mortality during the winter months ${ }^{(18)}$. These conditions are particularly important for the seasonality of viral infections, mainly by RSV ${ }^{(15,19-21)}$, as observed in the present study.

The prevalence of positive RSV was $30.7 \%$, being almost $40 \%$ in bronchiolitis, similar to that reported in the literature, with 30 to $40 \%$ rate of positive RSV in bronchiolitis ${ }^{(22-26)}$ by immunofluorescence. High positive rates, varying from 70 to $80 \%$ were observed when other diagnostic methods, such as culture and serology, were associated to immunofluorescence ${ }^{(20,21)}$. Financial problems did not allow these techniques to be performed in the present study.

The presence of RSV was detected in the nasopharyngeal secretion in $25 \%$ of children with AOM. The significance of viral infections as a triggering element of inflammatory alterations in the upper airway that foster growth of secretion in the middle ear and subsequent bacterial proliferation is well known ${ }^{(27)}$. There is, however, evidence suggesting that some kinds of viruses and, particularly RSV, may actively invade the middle ear, contributing directly in the pathogenesis of $\mathrm{AOM}^{(28)}$.

The results of the present study emphasize the importance of ARDs as a significant cause of morbidity during infancy, particularly in the first year of life, confirming its seasonality and association with RSV.

\section{REFERENCES}

1. Brasil. Ministério da Saúde. Manual de normas para infecção respiratória aguda. Sociedades Brasileiras de Pediatria e Pneumologia, $1991 ; 1-27$.

2. Antuñano FJL. Epidemiologia das infecções respiratórias agudas em crianças: panorama regional. In: Benguigui Y, Schmunis G, Yunes J, editores. Infecções respiratórias em crianças, FJLA. Washington: Organização Pan-Americana da Saúde, 1998;3-19.

3. Chatkin JFM. A epidemiologia das infecções respiratórias agudas em menores de cinco anos no Rio Grande do Sul, Brasil. In: Benguigui Y, editor. Investigações operacionais sobre o controle das infecções respiratórias agudas (IRA). Washington: Organização Pan-Americana da Saúde, 1997;6170.

4. Victora CG, Barros FC, Halpern R, Menezes AMB. Estudo longitudinal da população materno-infantil da região urbana do Sul do Brasil, 1993: aspectos metodológicos e resultados preliminares. Rev Saúde Pública 1996;30:34-45.

5. Amaral JJF. Prevalência e fatores de risco para infecção respiratória aguda em crianças aos seis meses de vida em Pelotas, RS. In: Departamento de Epidemiologia e Medicina Preventiva. Pelotas: Universidade Federal de Pelotas, 1995;71.

6. Weissembacher MC, Ávila MM. Os vírus como causa de IRA alta e baixa em crianças: características gerais e diagnóstico. In: Benguigui Y, Schmunis G, Yunes J, editores. Infecções respiratórias em crianças, F.J.L.A. Washington: Organização Pan-Americana da Saúde, 1998; 91-103.

7. Tsai HP, Kuo PH, Liu CC, Wang JR. Respiratory viral infections among pediatric inpatients and outpatients in Taiwan from 1997 to 1999 . J Clin Microbiol 2001;39:111-8.

8. Brasil. Ministério da Saúde. Morbidade hospitalar do SUS-CID-10, 1999, SIH/SUS. [acesso 2000 jul 16]. Disponível em: http://www. datasus.gov.br.

9. Brasil. Ministério da Saúde. Morbidade hospitalar do SUS-CID-10, 2000, SIH/SUS. [acesso 2000 jul 16]. Disponível em: http://www.datasus.gov.br. Ministério, Morbidade hospitalar do SUS-CID-10. 1999, SIH/SUS.

10. Weber MW, Milligan P, Sanneh M, Awemoyi A, Dakour R, Schneider G, et al. An epidemiological study of RSV infection in the Gambia. Bull World Health Organ 2002;80:562-8.

11. Avalos V, Bejares M, Durán F, Young T, Sagues CR, Torres JP. Campaña de invierno 1998: descripción de los niños hospitalizados en el servicio de pediatría del Hospital San Juan de Dios. Bol Hosp San Juan Dios 2000;47:15-20.

12. Chan PW, Goh AY, Chua KB, Kharullah NS, Hooi PS. Viral aetiology of lower respiratory tract infection in young Malaysian children. J Pediatr Child Health 1999;35:287-91.

13. Nohynek H, Eskola J, Laine E, Halonen P, Ruutu P, Saikku P, et al. The causes of hospital-treated acute lower respiratory tract infection in children. Am J Dis Child 1991;145:618-22.

14. Banajeh SM. Outcome for children under 5 years hospitalized with severe acute lower respiratory tract infections in Yemen: a 5-year experience. J Trop Pediatr 1998;44:343-6.

15. Carballal G, Videla CM, Espinosa MA, Savy V, Uez O, Sequeira MD, et al. Multicentered study of viral acute lower respiratory infections in children from four cities of Argentina, 1993-1994. J Med Virol 2001; 64:167-74.

16. Hussey GD, Apolles P, Arendse Z, Yeates J, Robertson A, Swingler G, et al. Respiratory syncytial virus infection in children hospitalized with acute lower respiratory tract infection. S Afr Med J 2000;90:509-12.

17. Victora CG, Kirkwood BR, Ashworth A, Black RE, Rogers S, Sazawal S, et al. Potential interventions for the prevention of childhood pneumonia in developing countries: improving nutrition. Am J Clin Nutr 1999;70:309-20.

18. Victora CG. Factores de riesgo en las IRA bajas. In: Benguigui Y, López Antuñano FJ, Schmunis G, editores. Infecciones respiratorias en niños. 1997;45-63.

19. Straliotto SM, Roitman B, Lima JB, Fischer GB, Siqueira MM. Respiratory syncytial virus (RSV) bronchiolitis: comparative study of RSV groups A and B infected children. Rev Soc Bras Med Trop 1994;27: 1-4.

20. Hayes EB, Hurwitz ES, Schonberger LB, Anderson LJ. Respiratory syncytial virus outbreak on American Samoa. Evaluation of risk factors. Am J Dis Child 1989;143:316-21. 
21. Murphy B, Phelan PD, Jack I, Uren E. Seasonal pattern in childhood viral lower respiratory tract infections in Melbourne. Med J Aust 1980; 1:22-4.

22. Sung RYT, Chan RCK, Tam JS, Cheng AFB, Murray HGS. Epidemiology and aetiology of acute bronchiolitis in Hong Kong infants. Epidemiol Infect 1992;108:147-54.

23. Savy V, Baumeister E, Bori F, Shiroma M, Campos A. Etiological and clinical evaluation of low acute respiratory infections in children. Medicina (B Aires) 1996;56:213-7.

24. Videla C, Carballal G, Misirlian A, Aguilar M. Acute lower respiratory infections due to respiratory syncytial virus and adenovirus among hospitalized children from Argentina. Clin Diagn Virol 1998;10:17-23.

25. Maitrey RS, Broor S, Kabra SK, Ghosh M, Seth P, Dar L, et al. Rapid detection of respiratory viruses by centrifugation enhanced cultures from children with acute lower respiratory tract infections. J Clin Virol 2000;16:41-7.

26. Lanari M, Giovannini M, Giffre L, Marini A, Rondini G, Rossi GA, et al. Prevalence of respiratory syncytial virus infection in Italian infants hospitalized for acute lower respiratory tract infections, and association between respiratory syncytial virus infection, risk factors and disease severity. Pediatr Pulmonol 2002;33:458-65.

27. Heikkinen T. The role of respiratory viruses in otitis media. Vaccine 2000;19 (Suppl 1):S51-5.

28. Heikkinen T, Thint M, Chommaitree T. Prevalence of various respiratory viruses in the middle ear during acute otitis media. $\mathrm{N}$ Engl $\mathrm{J}$ Med 1999;340:260-4. 